\title{
The Argentine crisis and its impact on household welfare
}

\author{
Ariel Fiszbein \\ World Bank \\ This study presents the initial findings of a household survey \\ afiszbein@worldbank.org \\ dealing with the effects of the Argentine economic crisis on \\ Paula Inés Giovagnoli \\ welfare. It also seeks to identify the coping mechanisms and \\ World Bank \\ strategies adopted by households in these difficult times. \\ pgiovagnoli@worldbank.org \\ Isidro Adúriz \\ The results obtained confirm the negative image reflected \\ Instituto Brasileiro de Opinião \\ in the macroeconomic indicators, identify the limitations of \\ Pública e Estatística \\ iaduriz@hotmail.com \\ the different coping mechanisms and reveal serious effects \\ on welfare. The evidence suggests that the effects on the \\ use of health services have been more marked than those on \\ the use of education services.
}


I

\section{Introduction}

Argentina is currently in the midst of a deep and unparalleled economic, social and political crisis. After three consecutive years of recession, the economic and financial crisis deepened during 2001. Various attempts were made during that year to restart growth as a prelude to improving the public finances and the debt profile, but to no avail. Efforts to halt a run on the banks (the corralito restricting withdrawals) constrained liquidity and economic activity and generated popular unrest. All this culminated in the resignation of President de la Rúa in December 2001, a quick succession of appointed presidents, a formal default on public-sector debt repayments and, in early 2002, the abandonment of the Convertibility Plan.

After four years of recession, the economy is projected to shrink by about $16 \%$ in 2002 , bringing the decline in GDP to over 25\% since its 1998 peak. With the peso depreciating sharply since its float and a lack of direction in monetary policy, Argentina is experiencing significant inflation for the first time since 1991. Between the decline in economic activity and the depreciation of the currency, per capita GDP has collapsed to a projected US $\$ 2,850$ in 2002 (down from US\$ 8,210 at its peak in 1998).

The downturn in the second half of 2002 sharply aggravated the already difficult social conditions in the country. Already high levels of unemployment (18.3\% in October 2001) jumped to 21.5\%, according to official figures for May 2002. ${ }^{1}$ Moreover, job losses

$\square$ This study was prepared and published as an informal paper in the Working Documents series of the World Bank Office for Argentina, Chile, Paraguay and Uruguay. The authors are grateful to Diane Steele, Esteban Font Guido, Miriam García and Irene Novakosky and to the SIEMPRo team, Sebastián Galiani, Sandra Cesilini, Kinnon Scott, Susana Aparicio, Polly Jones, Martín Ravallion, Florencia Castro Leal and Emanuela Galasso for their invaluable help with the survey. They also wish to thank Truman Packard, Indermit Gill, Leonardo Gasparini, Guillermo Cruces, Carlos Cavalcanti, Juan Gaviria, Carlos Sobrado, Estanislao Gacitúa and Chris Chamberlin for their comments and suggestions and Enrique Zuleta Puceiro for his guidance in the design and implementation of the survey. The views expressed here are those of the authors and should not be attributed to the World Bank.

${ }^{1}$ Instituto Nacional de Estadísticas y Censos (INDEC), Standing Household Survey (Encuesta Permanente de Hogares - EPH), urban areas total. (particularly unskilled jobs) have been widespread. During the first quarter of 2002 the construction industry (vital for unskilled labour) shrank by $25 \%$ with respect to the last quarter of 2001 (42\% with respect to the first quarter of 2001). ${ }^{2}$ Poverty is also on the increase, confirming the link between economic crises and rising poverty (Lustig, 2000). Official estimates for 28 urban centres indicate that poverty rose from $38.3 \%$ in October 2001 to 53\% in May 2002. This extremely negative environment has also had a strong impact on the health and education sectors, where there is growing evidence of deterioration in service delivery. The combination of all these factors has resulted in an increasingly fraught social situation with high levels of crime, violence and protests of various kinds.

This paper summarizes the initial results of a household survey conducted expressly to gauge the effects of the economic crisis on household welfare and identify the coping mechanisms and strategies adopted by Argentine families in these hard times. Specifically, the survey was designed to identify changes in income, consumption patterns, access to social and other services, saving and payment patterns, labour-market participation and reliance on formal and informal safety-net mechanisms. Additionally, the survey sought to collect information on changes in the mental and emotional state of individuals.

The survey is nationally representative, covering 2,800 households in different regions. ${ }^{3}$ Unlike most other surveys in Argentina, including the INDEC Standing Household Survey (Encuesta Permanente de Hogares - EPH), this one included small settlements (less than 2,000 inhabitants) and thus provides a better insight into such areas. It did not include areas of scattered population, however, and thus does not present a full picture of Argentina's heterogeneous rural sector. For urban areas, the sample design was based on a stratification by city size and by region. Settlements in rural areas were selected randomly. While an effort was made to include settlements in different regions, the sample was not large enough to be representative at

\footnotetext{
${ }^{2}$ Encuesta de Indicadores Laborales (EIL), Ministry of Labour.

${ }^{3}$ The survey was conducted by the Instituto Brasileiro de Opinião Pública e Estatística (IBOPE).
} 
the regional level. Overall, the survey design allows comparisons with the Standing Household Survey for urban areas.

The first part of the questionnaire asked for information on all household members and included questions on demographic characteristics, employment, income, migration status, education level, health coverage and social security contributions. Several of these questions were retrospective, using October 2001 as the reference point. Individuals were asked about their individual employment and non-employment income (cash and kind) and about official and unofficial income transfers.

\section{II}

\section{Main findings}

\section{Household income}

Table 1 presents the basic information on incomes yielded by the survey. Reported monthly per capita income from all sources averaged 214.6 pesos. ${ }^{5}$ This compares with an average income of 233 pesos estimated by INDEC for urban areas in May 2002. Standard procedures were used to adjust per capita income using the adult-equivalency scale (to reflect differences in consumption needs), yielding an average monthly income of 264 pesos. Some standard inequality measures are also presented, and these confirm the relatively high level of income inequality observed in the Argentine household surveys.

As mentioned earlier, a special feature of this survey is the inclusion of rural areas that are not covered by the Standing Household Survey. Table 2 confirms

${ }^{4}$ If the household head did not know the answer to a particular question (e.g., changes in consumption patterns) the household was visited up to three times to find a member who did.

${ }^{5}$ Owing to the known difficulties that household surveys have in obtaining reliable data on income levels, a question was devised for those respondents who preferred not to report the exact amount of their earnings. They were asked to select the range that best reflected their own income (which was imputed by taking the average of each interval). This allowed the number of households with incomplete information on income to be reduced from $17.2 \%$ to $7.6 \%$. When individuals did not report their earnings from work, these were estimated using Mincer equations, whereby the logarithm of hourly earnings is defined as a function of observable individual attributes such as sex, education, age and experience. The Heckman method was used to correct for selection bias. The absolute and relative effects of these corrections on incomes are insignificant (per capita income increases from 212 pesos to 214 pesos) (Heckman, 1979, pp. 153-161).
The second part of the questionnaire took the household as its unit of analysis. The questions were answered by the head of household (or the best informed individual in the household). ${ }^{4}$ Questions were asked on the use of savings, changes in consumption patterns and participation in social programmes and community activities. Respondents were also asked about their mental and emotional state and their expectations for the future. The questionnaires for urban and rural areas differed slightly to capture specificities related to those areas. The fieldwork was conducted in June and July 2002.
TABLE 1

Argentina: Mean income, by quintile, June 2002

\begin{tabular}{|c|c|c|c|c|}
\hline \multirow[t]{2}{*}{ Quintile } & \multicolumn{2}{|c|}{$\begin{array}{l}\text { Adult-equivalent } \\
\text { household income } \\
\text { (pesos) }\end{array}$} & \multicolumn{2}{|c|}{$\begin{array}{c}\text { Per capita } \\
\text { household } \\
\text { income }\end{array}$} \\
\hline & Mean (pesos) & Share $(\%)$ & Mean (pesos) & Share $(\%)$ \\
\hline $\mathrm{I}^{\mathrm{a}}$ & 40.5 & 3.1 & 32.0 & 3.0 \\
\hline II & 107.4 & 8.1 & 85.9 & 8.0 \\
\hline III & 182.7 & 13.8 & 146.3 & 13.7 \\
\hline IV & 300.1 & 22.7 & 240.9 & 22.5 \\
\hline V & 690.8 & 52.3 & 564.7 & 52.8 \\
\hline Mean & 264.3 & 100 & 214 & 100.0 \\
\hline $\mathrm{Y} 10 / \mathrm{Y} 1^{\mathrm{b}}$ & 28.9 & & 28.4 & \\
\hline $\begin{array}{l}\text { Gini } \\
\text { coefficier }\end{array}$ & ent 0.473 & & 0.478 & \\
\hline
\end{tabular}

${ }^{a}$ First quintile includes households reporting zero income.

b $\mathrm{Y} 10 / \mathrm{Y} 1$ is the ratio of mean incomes in the highest and lowest deciles of the distribution. Y1 does not include those reporting zero income.

TABLE 2

Argentina: Mean income, by areas (Pesos)

\begin{tabular}{lcc}
\hline Areas & $\begin{array}{c}\text { Adult-equivalent } \\
\text { household income } \\
\text { (pesos) }\end{array}$ & $\begin{array}{c}\text { Per capita household } \\
\text { income } \\
\text { (pesos) }\end{array}$ \\
\hline Urban & 268.3 & 223.27 \\
Rural & 168.9 & 142.13 \\
\hline
\end{tabular}


the well known (but not necessarily well established) fact that urban incomes are higher, with a gap of about $60 \%$.

To identify the effects of the crisis on family incomes, the survey asked each household to state whether its current income had changed (in nominal terms) from what it was in October 2001. Table 3 shows that over $40 \%$ of households reported no change in income while almost $50 \%$ reported a reduction in nominal income. Interestingly, about $8 \%$ of households reported higher incomes.

The information collected gives no indication of the extent to which these changes influenced income distribution, as the retrospective questions did not refer to "levels" of income. Table 4, however, shows the incidence of change according to the education level of the head of household, a proxy for household income.

It is interesting to note that the highest incidence of income loss was in households headed by individuals with secondary education, a group that tends to be located in the middle of the income distribution ("the middle class"), while the lowest incidence was in households headed by individuals with incomplete primary education, a group that tends to be at the bottom of the income distribution scale ("the indigent"). This information suggests that the middle classes might have been the most seriously affected by the economic crisis. $^{6}$

The case of the approximately $8 \%$ of households reporting an increase in income since October 2001 is of particular interest, given the extremely negative economic performance during this period. Table 5 provides some clues to the main reasons behind this increase in nominal incomes.

In almost half the cases, the reported increase in income is associated with a change in employment characteristics: a new worker in the family (most in temporary, informal jobs), a move to a better paying job, or more hours worked. The other half of the cases do not show any noticeable change in employment characteristics for any of the household members. In a little over $20 \%$ of cases, it is possible to identify an increase in non-employment incomes as the principal source of change.

\section{Employment}

The survey also inquired about the employment status of individuals and changes in this respect since October

${ }^{6}$ During the 1990 s, by contrast, economic shocks had a profounder effect on the poor and those with the lowest education levels. See World Bank (2000 and 2001).
TABLE 3

\section{Argentina: Changes in income}

\begin{tabular}{lc}
\hline Since October 2001 & $\%$ \\
\hline Increased & 8.0 \\
No change & 43.4 \\
Decreased & 48.6 \\
\hline
\end{tabular}

TABLE 4

Argentina: Changes in income, by education level of household head

\begin{tabular}{lrrrr}
\hline & \multicolumn{4}{c}{ Education level } \\
\cline { 2 - 5 } & Increased & No change & Decreased & Total \\
\hline $\begin{array}{l}\text { Incomplete primary } \\
\text { education }\end{array}$ & 4.25 & 50.14 & 45.61 & 100 \\
Primary education & 7.81 & 44.85 & 47.34 & 100 \\
$\begin{array}{l}\text { Incomplete secondary } \\
\text { education }\end{array}$ & 15.44 & 34.52 & 50.04 & 100 \\
$\quad$ Secondary education & 6.72 & 39.51 & 53.77 & 100 \\
Incomplete higher & & & & \\
$\quad$ education & 6.83 & 45.94 & 47.23 & 100 \\
Higher education & 8.91 & 41.24 & 49.85 & 100 \\
Total & 8.07 & 43.22 & 48.71 & 100 \\
\hline
\end{tabular}

TABLE 5

\section{Argentina: Households reporting} higher incomes

\begin{tabular}{lc}
\hline Reason & $\%$ \\
More people working & 15.0 \\
Changed jobs & 14.1 \\
Worked more hours & 14.4 \\
Same job/same hours & 31.7 \\
Higher non-employment income & 22.3 \\
Other & 2.5 \\
\hline
\end{tabular}

TABLE 6

Argentina: Employment, May/June 2002 (Percentages)

\begin{tabular}{lcc}
\hline & $\begin{array}{c}\text { May/June } \\
2002\end{array}$ & $\begin{array}{c}\text { October } \\
2001\end{array}$ \\
\hline Employment rate & 29.9 & $31.1^{\mathrm{a}}$ \\
Activity rate & 39.8 & $39.8^{\mathrm{a}}$ \\
Unemployment rate & 24.9 & $22.0^{\mathrm{a}}$ \\
Unemployment rate $(\mathrm{EPH})$ & 21.5 & 18.3 \\
\hline
\end{tabular}

${ }^{\text {a }}$ Based on retrospective information from survey respondents.

2001. The results indicate a stable activity rate (i.e., no net change in labour-force participation) of about $40 \%$, with an increase in the unemployment rate of about $3 \%$ combined with a reduction in the employment rate (as a proportion of the population) of slightly more than

THE ARGENTINE CRISIS AND ITS IMPACT ON HOUSEHOLD WELFARE • ARIEL FISZBEIN, PAULA INÉS GIOVAGNOLI 
Argentina: Changes in employment status

(Thousands and percentages)

\begin{tabular}{|c|c|c|c|c|c|c|c|}
\hline & \multicolumn{7}{|c|}{ Previous status } \\
\hline & & & Unemployed & Inactive & Permanent job & Temporary job & Total \\
\hline \multirow{5}{*}{ 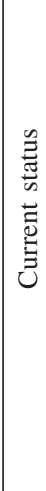 } & Unemployed & $\begin{array}{c}1000 \mathrm{~s} \\
\%\end{array}$ & $\begin{array}{c}1435 \\
50.6\end{array}$ & $\begin{array}{c}1228 \\
6.2\end{array}$ & $\begin{array}{r}15 \\
0.2\end{array}$ & $\begin{array}{l}555 \\
17.1\end{array}$ & $\begin{array}{c}3233 \\
9.9\end{array}$ \\
\hline & Inactive & $\begin{array}{c}1000 \mathrm{~s} \\
\%\end{array}$ & $\begin{array}{c}1039 \\
36.7\end{array}$ & $\begin{array}{c}18252 \\
92.5\end{array}$ & $\begin{array}{l}20 \\
0.3\end{array}$ & $\begin{array}{l}386 \\
11.9\end{array}$ & $\begin{array}{c}19696 \\
60.0\end{array}$ \\
\hline & Permanent job & $\begin{array}{c}1000 \mathrm{~s} \\
\%\end{array}$ & $\begin{array}{l}113 \\
4.0\end{array}$ & $\begin{array}{l}91 \\
0.5\end{array}$ & $\begin{array}{c}6498 \\
92.6\end{array}$ & $\begin{array}{l}331 \\
10.2\end{array}$ & $\begin{array}{c}7034 \\
21.4\end{array}$ \\
\hline & Temporary job & $\begin{array}{c}1000 \mathrm{~s} \\
\%\end{array}$ & $\begin{array}{l}247 \\
8.7\end{array}$ & $\begin{array}{l}153 \\
0.8\end{array}$ & $\begin{array}{l}485 \\
6.9\end{array}$ & $\begin{array}{c}1969 \\
60.8\end{array}$ & $\begin{array}{c}2854 \\
8.7\end{array}$ \\
\hline & Total & $\begin{array}{c}1000 s \\
\%\end{array}$ & $\begin{array}{c}2834 \\
100\end{array}$ & $\begin{array}{c}19725 \\
100\end{array}$ & $\begin{array}{c}7018 \\
100\end{array}$ & $\begin{array}{c}3241 \\
100\end{array}$ & $\begin{array}{c}32817 \\
100\end{array}$ \\
\hline
\end{tabular}

1\%. The Standing Household Survey (EPH) found a similar increase in the unemployment rate (from $18.3 \%$ to $21.5 \%$ ) in 28 urban centres, although the levels were slightly different.

These aggregate numbers mask significant changes in the employment position of specific households. Table 7 provides a summary of these, using the answers to the retrospective questions to focus on changes in employment status between October 2001 and the time of the survey.

The stability of labour-force participation can be confirmed by comparing the numbers in the "inactive" category on the two sides of the matrix. The number of individuals leaving the workforce (most of them previously unemployed) is similar to the number entering (most of whom remain unemployed). A more detailed analysis shows that these are mostly "secondary earners" in households which have another member working.

Unsurprisingly, the number of individuals losing jobs exceeds the number finding them. As table 8 shows, those moving out of unemployment are more likely to be secondary workers than those losing their jobs, indicating some changes in family roles which will be analysed later.

The third factor worth mentioning is an apparent deterioration in the "quality" of jobs. This is reflected in the type of employment reported both by those who obtained new jobs (which tended to be temporary rather than permanent and, if permanent, more likely than not to be completely lacking in standard formal-sector
TABLE 8

Argentina: Groups experiencing change, by position in household and gender

\begin{tabular}{lcc}
\hline & $\begin{array}{c}\text { Unemployed to } \\
\text { employed (\%) }\end{array}$ & $\begin{array}{c}\text { Employed to } \\
\text { unemployed (\%) }\end{array}$ \\
\hline $\begin{array}{l}\text { Position in household } \\
\text { Head of household }\end{array}$ & 35.9 & 57.0 \\
Spouse & 18.8 & 12.6 \\
Others & 45.3 & 30.4 \\
Total & 100.0 & 100.0 \\
Gender & & \\
Male & 58.4 & 62.0 \\
Female & 41.6 & 38.0 \\
& & 100.0 \\
Total & 100.0 & \\
\hline
\end{tabular}

benefits) and those who changed jobs (a net increase in the proportion of temporary jobs and, in the case of new permanent jobs, a high proportion without benefits). Approximately $6 \%$ of those in work reported losing at least some type of benefit. This is consistent with the trend revealed by the Standing Household Survey. ${ }^{7}$

The sharp deterioration in formal-sector employment is confirmed independently by the Ministry of Labour Survey of Employment Indicators (Encuesta de Indicadores Laborales - EIL), which

\footnotetext{
${ }^{7}$ For example, the proportion of wage earners without benefits increased from $33 \%$ to $35 \%$ between the October 2001 and May 2002 Standing Household Surveys.
} 
covers more than 1,500 firms representing a universe of approximately 38,000 companies of various sizes and in different sectors that employ approximately 1.9 million registered workers in the three largest urban centres (Greater Buenos Aires, Greater Rosario and Greater Córdoba). As figure 1 shows, formal employment is estimated to have fallen by $7.4 \%$ since October 2001, and by $10.5 \%$ since June $2001 .^{8}$

\section{Poverty}

On the basis of the income data for June, the incidence of poverty was estimated using four different lines. First, we used the official "poverty" and "indigence" lines estimated by INDEC for the month of June $2002 .{ }^{9}$ For rural areas, use was made of the poverty line for the urban centre in the same region. This does not take account of potential urban/rural price differences, of course, but it does at least control for regional differences (World Bank, 2001). ${ }^{10}$ In addition, a one dollar and two dollar a day poverty line was constructed using the standard World Bank methodology for the country as a whole. ${ }^{11}$ The national results are shown in table 9 .

Table 10 gives the results for urban and rural areas.

A few points should be highlighted. First, the incidence of poverty/indigence (using the official lines) confirms the predictions made in the early stages of the crisis, which suggested poverty rates of about $50 \%$ and indigence rates of about $25 \%$. Official estimates from the Standing Household Survey yield similar poverty and indigence rates $(53 \%$ and $24.8 \%$, respectively), although with narrower coverage owing

\footnotetext{
${ }^{8}$ Additional data supplied by the Administración Federal de Ingresos Públicos (AFIP) give similar results: the monthly jobs total was $10.1 \%$ lower in the first quarter of 2002 than in the same period the previous year.

${ }^{9}$ The basic food baskets were originally estimated for each urban centre on the basis of 1997 consumption patterns and were adjusted to reflect April 2001 prices in each centre using the INDEC consumer purchasing power parity index for that month. The lines were then updated to the month of June using the variation in prices in Greater Buenos Aires. The absence of systematic price information for all urban centres is a serious limitation. Comparison of changes in food prices in Buenos Aires, Córdoba, Mendoza and Tucumán during the first six months of 2002 shows a slightly larger increase in the interior than in Greater Buenos Aires.

${ }^{10}$ A more in-depth analysis of poverty in rural areas will be conducted separately.

${ }^{11}$ The poverty lines were constructed using the 1993 purchasing power parity $(\mathrm{PPP})$ index for Argentina $(\mathrm{PPP}=0.7779)$ and were converted into local prices using the consumer price index (CPI).
}

FIGURE 1

Greater Buenos Aires: Formal employment

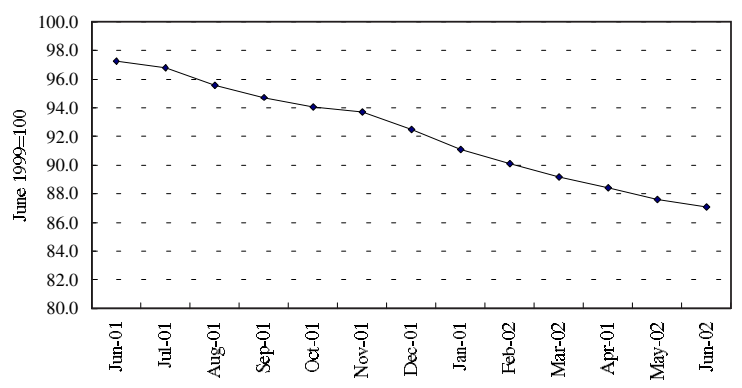

Source: Encuesta de Indicadores Laborales (EIL).

TABLE 9

Argentina: Poverty indices, June 2002

(Percentages of individuals)

\begin{tabular}{lccc}
\hline & $\begin{array}{c}\text { World Bank } \\
\text { survey } \\
\text { June 2002 }\end{array}$ & \multicolumn{2}{c}{$\begin{array}{c}\text { Standing Household } \\
\text { Survey (EPH) }\end{array}$} \\
\cline { 3 - 4 } & May 2002 & October 2001 \\
\hline Poverty & 53.7 & 53.0 & 38.3 \\
Indigence & 23.8 & 24.8 & 13.6 \\
PPP (1 dollar) & 9.9 & 9.5 & 7.5 \\
PPP (2 dollars) & 24.6 & 20.8 & 17.1 \\
\hline
\end{tabular}

TABLE 10

Argentina: Poverty indices

by areas, June 2002

(Percentages of individuals)

\begin{tabular}{lcc}
\hline & Urban & Rural \\
\hline Poverty & 52.9 & 72.6 \\
Indigence & 23.2 & 40.1 \\
\hline
\end{tabular}

to the exclusion of rural areas from the survey. Second, bearing all the necessary considerations in mind, it is important to note that the two dollar a day poverty line is very close to the official indigence line which, in principle, gives a better sense of how poverty in postdefault Argentina compares to international levels. Third, and again with all the necessary methodological caveats, even though the incidence of poverty/indigence is, as expected, much higher in rural areas, including these areas in the estimation does not have a significant effect on national rates, given the relative size of the two groups.

\section{Subjective welfare}

With the exploratory purpose of identifying changes in the mental and emotional state of individuals ("how

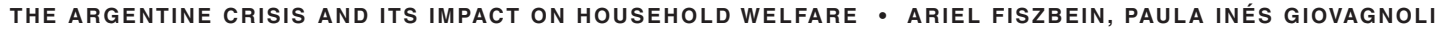


TABLE 11

Argentina: Changes of emotional state

(Percentages)

\begin{tabular}{|c|c|c|c|c|}
\hline & \multicolumn{2}{|c|}{ Feel discouraged } & \multicolumn{2}{|c|}{ Feel hopeless about the future } \\
\hline & Now & Before October 2001 & Now & Before October 2001 \\
\hline Never & 26.8 & 47.8 & 21.1 & 45.5 \\
\hline Sometimes & 34.2 & 37.3 & 33.2 & 36.2 \\
\hline Often & 24.8 & 9.6 & 27.5 & 11.3 \\
\hline Always & 13.5 & 4.0 & 16.7 & 4.8 \\
\hline No response & 0.6 & 1.3 & 1.5 & 2.2 \\
\hline Total & 100 & 100 & 100 & 100 \\
\hline
\end{tabular}

people feel"), the survey asked people whether they "felt discouraged" and/or "hopeless about the future". They were asked to identify the main reasons for these feelings and say how they felt before October 2001 .

As table 11 shows, the survey indicates a high and increasing incidence of discouragement and pessimism among respondents (mostly heads of household). Table 12 provides further evidence for the source of this discouragement/pessimism among those reporting such feelings. "Economic reasons" predominate over all others.

In the case of those who said they felt discouraged now but not before October 2001, the aim was to ascertain whether this change was associated with the respondent's employment position. As table 13 shows, this does not appear to be the case. Similarly, there was no identifiable pattern associated with income distribution. These findings suggest that the economic crisis affected people's emotional state across the board.

\section{Social unrest}

The survey confirms a sizeable increase in the participation of individuals in various forms of social protest, which rose from $7.6 \%$ before October 2001 to $16.2 \%$. Interestingly, participation increases up the income distribution scale. This is consistent with another finding of the survey: the most popular form of protest was the cacerolazo, or pot-banging $(9.2 \%$ participated), a form of protest that became highly popular in the major urban centres during the first quarter of 2002. ${ }^{12}$

Violence appears to be an important factor in the post-crisis period. As table 15 shows, 20\% of

${ }^{12}$ Lower-income groups participated mainly in pickets or road blockades.
TABLE 12

Argentina: Reasons for emotional state (Percentages)

\begin{tabular}{lcc}
\hline & $\begin{array}{c}\text { Feel } \\
\text { discouraged }\end{array}$ & $\begin{array}{c}\text { Feel hopeless } \\
\text { about the future }\end{array}$ \\
\hline Cannot find a job & 11.3 & 12.7 \\
Difficulties with job & 1.6 & 1.6 \\
Economic reasons & 53.4 & 54.0 \\
Health reasons & 4.8 & 3.0 \\
Something hard to explain & 16.1 & 15.4 \\
Other reasons & 12.8 & 13.4 \\
Total & 100.0 & 100 \\
\hline
\end{tabular}

TABLE 13

Argentina: Employment position of those stating they were more discouraged

\begin{tabular}{lc}
\hline Current position & $\%$ \\
\hline Employed & 46.4 \\
Unemployed & 14.5 \\
Retired & 15.1 \\
Student & 3.4 \\
Housewife & 10.4 \\
Other inactive & 10.1 \\
Total & 100.0 \\
\hline
\end{tabular}

households claimed to have fallen victim to crime or violence in the previous six months. It is interesting to note that while the highest-income group reported the highest incidence of crime or violence, there is no simple correlation between income level and the likelihood of experiencing crime.

The data are consistent with the information collected by the Dirección Nacional de Política Criminal for Greater Buenos Aires, Rosario and Córdoba, which indicated that $13 \%$ of respondents had

tHe ARGENTINE CRISIS AND ITS IMPACt ON HOUSEHOLd WELFARE • ARIEL FISZBEIN, PAULA INÉS GiOVAGNOLI 
TABLE 14

Argentina: Participation in social protests

(Percentage of households participating)

\begin{tabular}{cccccccc}
\hline Quintile & I & II & III & IV & V & Total & Total before October 2001 \\
\hline & 11.4 & 12.6 & 17.5 & 17.5 & 22.0 & 16.2 & 7.6 \\
\hline
\end{tabular}

TABLE 15

Argentina: Exposure to crime and violence

(Percentage of households)

\begin{tabular}{|c|c|c|c|c|c|c|}
\hline Quintile & I & II & III & IV & $\mathrm{V}$ & Total \\
\hline & 19.7 & 22.9 & 14.5 & 19.9 & 25.3 & 20.4 \\
\hline
\end{tabular}

experienced some type of crime during 2000 (Dirección Nacional de Política Criminal, 2000). The information does not show significant differences among socioeconomic groups but does reveal that higher-income groups are more likely to report crime (particularly car thefts).

\section{III}

\section{Coping strategies}

In this third section, the focus is on strategies adopted by households to cope with the crisis. First, there is a general description of the main types of strategies followed by households. These are grouped into three categories: i) adaptive household strategies, ii) active household strategies and iii) social network strategies (Loskin and Yemtsov, 2001). This is followed by analysis of the components of each category and identification of patterns indicating that certain strategies tend to be followed by different types of households (depending on income level, for example). It must be stressed that this is a first, exploratory step to prepare the way for a subsequent multivariate analysis of coping strategies.

\section{Overview}

As indicated earlier, the survey asked about the strategies most frequently used by households to cope with the worsening economic conditions experienced over the previous eight months.

The first set of strategies, which have been grouped under the term adaptive household strategies, includes those of households that responded to the crisis by changing their consumption patterns, including the use of various types of services. The second set of strategies, termed active household strategies, involves making increased use of the physical, financial and human assets available to the household. These strategies include bringing further household members into the workforce, working longer hours, selling assets, using savings, borrowing and migration. The last group, social network strategies, includes strategies that rely on assistance from friends, family, non-governmental organizations (NGOs) or the government.

Table 16 summarizes the key information on the use of these different strategies by families generally and, more specifically, by families whose household income fell.

A first aspect to be noted is that almost all households, regardless of whether they experienced changes in income, said they had altered their consumption patterns in response to the economic crisis. This is true across the income distribution spectrum (table 17). Argentine families have, indeed, adapted to the economic crisis by changing their consumption patterns.

Furthermore, with the exception of active strategies, which tend to be used more intensively by households whose income has fallen, no noticeable pattern is observed between the two groups in the use made of this broad set of coping strategies. However, when attention is focused on income groups (table 17), regardless of whether or not income has fallen, it becomes apparent that the use of social network strategies is strongly correlated with income levels.

Over and above these general patterns, as will be seen below, significant differences are found among

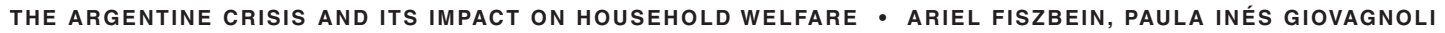


TABLE 16

Argentina: Use of strategies by households

\begin{tabular}{lcc}
\hline & $\%$ of households using & $\%$ of households where income has fallen using \\
\hline i) Adaptive strategies & 98.2 & 99.1 \\
ii) Active strategies & 37.3 & 45.0 \\
iii) Social network strategies & 32.7 & 36.4 \\
& 1.5 & 0.8 \\
Do not use any of these strategies & 98.5 & 99.2 \\
Use at least one of them & 54.7 & 61.6 \\
Use at least two of them & 13.6 & 17.8 \\
Use all of them & & \\
\hline
\end{tabular}

TABLE 17

Argentina: Use of strategies, by income quintile ${ }^{a}$

(Percentage of households using them in each quintile)

\begin{tabular}{lccccc}
\hline Quintile & I & II & III & IV & Total \\
\hline i) Adaptive strategies & 99.8 & 98.1 & 98.9 & 97.3 & 96.6 \\
ii) Active strategies & 47.0 & 37.7 & 36.1 & 30.5 & 30.7 \\
iii) Social network strategies & 55.5 & 39.1 & 38.4 & 24.2 & 12.0 \\
\hline
\end{tabular}

a The quintiles in this section are constructed with the same number of households in each, ranked by family income adjusted for household size (using adult equivalents) and excluding households for which information is incomplete.

TABLE 18

Argentina: Use of adaptive strategies, by income quintile

\begin{tabular}{|c|c|c|c|c|c|c|}
\hline Changes in consumption patterns & I & II & III & IV & $\mathrm{V}$ & Total \\
\hline \multicolumn{7}{|l|}{ Food } \\
\hline Lower consumption & 90.4 & 83.1 & 73.2 & 69.0 & 59.1 & 74.9 \\
\hline Switch to cheaper products & 97.6 & 95.4 & 92.5 & 91.5 & 84.8 & 92.3 \\
\hline \multicolumn{7}{|l|}{ Other goods } \\
\hline Lower consumption & 90.5 & 87.7 & 81.5 & 76.8 & 68.3 & 81.0 \\
\hline Switch to cheaper products & 89.5 & 89.3 & 80.4 & 80.2 & 76.6 & 83.2 \\
\hline Purchase of second-hand products & 51.7 & 40.2 & 34.8 & 33.0 & 24.3 & 36.7 \\
\hline Dispensing with/reducing use of domestic service ${ }^{a}$ & $\ldots$ & $\ldots$ & 43.0 & 27.8 & 40.5 & 37.9 \\
\hline
\end{tabular}

${ }^{a}$ Estimated only for those households for which this was an option and only when a sufficient number of cases was observed.

the various groups once the broad categories are broken down.

\section{Household adaptation strategies}

Table 18 summarizes the types of changes made by households in their expenditure patterns. What it reveals in particular is a tendency to reduce consumption levels and switch to cheaper products. A distinction is made between essential (food) and non-essential (other) items.

Broadly speaking, table 18 shows that all families have reacted to the economic crisis by combining lower consumption with a switch to cheaper goods, be these essential or non-essential. ${ }^{13}$ Having said this, two patterns can be discerned. Firstly, and unsurprisingly, higher-income groups appear to have avoided such changes to a greater extent. This is particularly true in the case of food, where the difference between income quintiles is striking. Secondly, switching to cheaper

\footnotetext{
${ }^{13}$ The consumer price index rose by $30 \%$ during the first six months of 2002. Food prices rose by more (39\%) than the average. Using the expenditure shares for the lowest quintile yielded by the 1997 consumption survey, we estimate that the cost of living for the poorest groups in society rose by $45 \%$ over the period.
} 
TABLE 19

Argentina: Have families taken children out of school?

\begin{tabular}{lcccc}
\hline & \multicolumn{3}{c}{ Going to school (\% of whole group) } & \multicolumn{2}{c}{ Estimated drop-out rate } \\
\cline { 2 - 4 } Age group & All areas & Urban areas & Rural areas & All areas \\
\hline 6 to 12 & 97.0 & 97.3 & 92.1 & 0.2 \\
13 to 15 & 92.5 & 92.5 & 90.9 & 0.6 \\
16 to 18 & 80.2 & 81.1 & 60.1 & 2.3 \\
\hline
\end{tabular}

products (or second-hand ones when available) appears to be a more common response than cutting consumption levels. In other words, the information suggests that families have tried to maintain food consumption as far as possible by reducing the consumption of other goods and switching to less expensive products. Not surprisingly, the lower-income groups seem to have been less successful at this.

The survey also reveals changes in use of and access to various types of services (specifically education, health and public services).

A question that deserves particular attention -and for which a separate analysis is being conducted using various sources of information-is whether there is any evidence of a higher school drop-out rate as a result of the economic crisis. Preliminary indications from the survey provide limited evidence of such an effect. Table 19 includes three age groups: 6 to 12,13 to 15 and 16 to 18 . The second column gives rough estimates of coverage rates for each group, without reference to the level of schooling. With all their limitations, these data confirm the rates traditionally ascertained from household surveys and show no sign of a decline in coverage.

The survey also sought to ascertain whether there was any indication that children reported as not attending school during the first months of the 2002 school year had actually dropped out. Household heads were asked whether anyone in the household (they were not required to say who $)^{14}$ had either dropped out of school or postponed attendance since October 2001. The third column shows what percentage of children in the age group concerned are not in school and belong to a family in which at least one member has dropped out of school or postponed attendance. Of course, this might mean that the numbers dropping out are overestimated if more than one household member

14 This avoided the "shame" effect that might have caused the numbers dropping out to be underreported, at the cost of losing information on exactly which member of the household was concerned. dropped out or delayed the start of classes (including higher education); this being the case, it is an estimate of the maximum potential size of the effect.

The first thing to be noted is that, given the very small number of cases involved, the estimates are not sufficiently precise (i.e., have a high coefficient of variation). Taking this into account, it is apparent that there is no evidence of children in the 6 to 12 or 13 to 15 age brackets dropping out and there is a small (but not statistically significant) percentage of drop-outs in the 16 to 18 group.

As a consistency test, we checked the latter group's position in the household income distribution. As table 20 shows, the few students who do seem to have dropped out belong mainly to the lowest deciles of the distribution, which does lend further plausibility to the evidence.

The limited evidence on changes in school dropout rates as a result of the crisis could indicate that families are trying hard under difficult circumstances to protect what is perhaps the most important type of investment they can make in their children (De Ferranti, Perry and others, 2000). Evidence from other crises suggests, however, that the negative effects might be felt not immediately but several months after the onset of the crisis (e.g., in 2003 enrolment rates). Furthermore, the data from the survey do not tell us how many children are not attending school regularly, which may be a more prevalent type of adjustment in many cases.

Table 21 provides some further evidence as to whether families made adjustments that affected their children's education. The percentage of families switching schools (to less expensive private schools or from private to State schools) is very small, suggesting an unwillingness to make such changes even in the face of a sharp economic deterioration.

On the other hand, a very large proportion of households (particularly in the lower income groups) ${ }^{15}$

\footnotetext{
${ }^{15}$ Almost $90 \%$ of households in the lowest income quintile reported cutting back their purchases of school materials, as against only $43 \%$ of those in the highest quintile.
} 
TABLE 20

Argentina: School drop-out rates

(Percentages)

\begin{tabular}{lc}
\hline Quintile & Proportion dropping out in the 16-18 group \\
\hline I & 53.9 \\
II & 23.3 \\
III & 6.3 \\
IV & 16.6 \\
V & 0 \\
\hline
\end{tabular}

TABLE 21

\section{Argentina: Adjustments in education expenditure \\ (Percentages of households)}

Switched from a private school to a State one Switched to a cheaper private school 2.0

Bought fewer school materials

reported reducing their purchases of school materials; the effects on the quality of schooling remain to be seen. The difficulties experienced by several provinces in keeping up spending levels suggest that restrictions on the supply side may be more serious than those on the demand side, at least at this early stage of the process.

In the case of health services, there is evidence of serious negative impacts since early 2002, in the form of difficulties both in the social health insurance system and the public health system. The information collected through the survey confirms the trends identified previously.

Approximately $12 \%$ of individuals experienced some change in health insurance coverage (table 22). More than $60 \%$ of these, mainly in the lowest-income groups, lost their coverage altogether. Of those whose health insurance coverage changed, this change was to lower coverage in $40 \%$ of cases. Almost half of those who were previously covered twice (by the obra social and prepaga systems) now maintained only their primary (obra social) health insurance. There was also a shift from full private insurance to emergency insurance only.

The loss of health insurance coverage is leading an increasing number of people to rely on public health facilities. Of those households reporting that they had switched from private coverage to public health services because of the economic crisis, $60 \%$ had lost their private coverage or seen it restricted in some way. More specifically, 16\% lost their coverage altogether, 5\% could not use it because they had debts outstanding, $13 \%$ could not afford to pay their share of services, $8 \%$

TABLE 22

Argentina: Changes in health insurance coverage

(Percentages of individuals experiencing a change in coverage)

\begin{tabular}{lcccccc}
\hline Quintile & I & II & III & IV & V & Total \\
\hline Lost all coverage & 76.0 & 61.1 & 78.6 & 52.6 & 33.6 & 61.4 \\
Changed coverage & 24.0 & 38.9 & 21.4 & 47.4 & 66.4 & 38.7 \\
\hline
\end{tabular}

experienced a reduction in the services covered by their insurers and $13 \%$ were retirees experiencing difficulties with the services offered by the Instituto Nacional de Servicios Sociales para Jubilados y Pensionados (PAMI). ${ }^{16}$

Overall, the survey found that families had cut back on health services in one way or another as a result of the economic crisis. A few findings are worth mentioning. Almost $23 \%$ of households reported that at least one member had been unable to obtain access to health services at some time. Three quarters of them gave the reason as a "lack of money" to pay for medicines (44\%), transportation costs $(25 \%)$ and contributions (5\%). More specifically, $37 \%$ of households with children under the age of 12 said they were taking their children for medical check-ups less often. Almost $45 \%$ of these households belonged to the lowest quintile of the income distribution. But this effect was also felt in the second $(29 \%)$ and third (18\%) quintiles.

Cutting down on the use of utility services appears to be another strategy followed by households. Typically, this involves either halting or delaying payments (with the risk of being cut off) or simply asking for the service to be suspended. Between 30\% and $50 \%$ of households said they had delayed payments. The percentage of households saying that various services had been cut off (electricity, gas, water, telephone, cable, Internet) ranged from $2 \%$ (in the case of the water supply) to $14 \%$ for cable television. In most cases, the main reason was non-payment.

Similarly, households have begun to make greater use of cheaper forms of transport, as table 23 shows. More than half of households that previously used only public transport now report that they are making more journeys by bicycle or on foot. A similar switch from cars and taxis to public transport is observed as well.

16 PAMI is the national health insurer for retirees.

THE ARGENTINE CRISIS AND ITS IMPACT ON HOUSEHOLD WELFARE • ARIEL FISZBEIN, PAULA INÉS GIOVAGNOLI 
TABLE 23

\section{Argentina: Changes in use of transport services}

\begin{tabular}{lcccccc}
\hline Quintile & I & II & III & IV & V & Total \\
\hline $\begin{array}{l}\text { From cars/taxis } \\
\text { to public } \\
\text { transport }\end{array}$ & 57.4 & 56.7 & 47.8 & 45.5 & 32.4 & 46.1 \\
$\begin{array}{l}\text { From cars/ } \\
\text { taxis/public }\end{array}$ & & & & & & \\
$\begin{array}{l}\text { transport to } \\
\text { cycling/walking } 73.9\end{array}$ & 62.5 & 61.3 & 49.0 & 33.5 & 55.4 \\
\hline
\end{tabular}

These figures are consistent with official data on the use of public services, ${ }^{17}$ according to which passenger numbers fell by $22 \%$ on urban railways, $9 \%$ on underground railways and $14 \%$ on metropolitan bus services in the first five months of 2002 (Estadísticas de Servicios Públicos, 2002).

\section{Active household strategies}

Table 24 summarizes some of the active measures adopted by households in response to the economic crisis. In only $13 \%$ of households did a new member enter the labour force.

This is a particularly important resource in the lowest-income group (table 25). The new worker is typically a secondary one: in $50 \%$ of cases it is the son or daughter and in $25 \%$ it is the spouse of the person identified as the household head. The effectiveness of this strategy, however, appears to be rather limited. A little over $13 \%$ of these new entrants succeed in finding a job, and those who are successful tend not to be the poorest.

Working longer hours appears to be another strategy followed by all income groups. However, it tends to be mostly salaried workers in permanent jobs, particularly in trade, that appear to succeed in the effort to increase working hours.

Alongside these changes in employment strategies, there is an observable tendency to replace leisure with work at home as a way of coping with the crisis. Two examples are worth mentioning. First, approximately $60 \%$ of households reported that they had increased

${ }^{17}$ Estadísticas de Servicios Públicos (2002). These statistics are collected monthly by INDEC and form the basis for its synthetic public services indicator (Indicador Sintético de Servicios Públicos - ISSP). the time allocated to the preparation of "home-made goods" (e.g., meals) to replace purchased goods. As table 25 shows, this strategy is widely used by the lowest-income groups. Second, households employing domestic workers cut back substantially on their use.

The survey also inquired whether a household member had migrated since October 2001 or if someone in the household was considering that option. On average, a little over $4 \%$ of households reported having at least one member that had emigrated, and this percentage held fairly steady across the income distribution. ${ }^{18}$ The main reasons for migration included "lack of work" (58\%) and the desire for a better quality of life (15\%). Again, more than $20 \%$ of households reported that at least one family member was considering migrating. The main option being considered ( $80 \%$ of households overall, with the largest proportion being found among the highest-income groups in the City of Buenos Aires) was emigration to another country.

Since the crisis began, a larger proportion of households have been using their savings, selling assets or borrowing to keep consumption levels up (see table 26).

Perhaps the most interesting finding is the degree to which lower-income households rely as a coping strategy on the informal credit granted by neighbourhood stores (compra al fiado), which enables them to delay payment (table 27).

\section{Social network strategies}

Table 28 summarizes some of the main indicators of social network use by households. Table 29 provides further information broken down by income group. Overall, more than a third of households report benefiting at least in some respect from access to a social support network. Use of such strategies is somewhat higher among households that experienced falls in nominal income (table 28) and significantly higher among households at the bottom of the income distribution scale (table 29).

The survey provides some evidence that social networks are used differently depending on income level. Certainly, if the income distribution is compared with the distribution of households claiming to have received assistance from or given it to people not living in their own household, it transpires that households in

${ }^{18}$ This excludes those emigrating as a result of marriage, sickness or other family reasons.

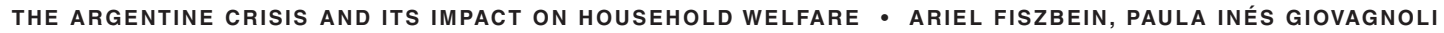


TABLE 24

\section{Argentina: Active household strategies}

\begin{tabular}{lcc}
\hline & $\%$ of households using & $\begin{array}{c}\% \text { of households that reported } \\
\text { a loss of income using }\end{array}$ \\
\hline $\begin{array}{l}\text { Labour-market strategies } \\
\text { Bringing new workers into the labour market }\end{array}$ & 13.4 & 16.1 \\
Working more hours & 14.8 & 19.2 \\
Time & 59.9 & 62.6 \\
Increasing production at home & 35.3 & 40.4 \\
Dispensing with/cutting back on domestic service & 4.1 & 3.9 \\
Migration & & \\
\hline
\end{tabular}

a The percentage for this item refers to households for which this category is relevant.

TABLE 25

\section{Argentina: Active household strategies, by income level}

\begin{tabular}{|c|c|c|c|c|c|c|}
\hline Quintile & I & II & III & IV & $\mathrm{V}$ & Total \\
\hline \multicolumn{7}{|l|}{ Labour-market strategies } \\
\hline Bringing new workers into the labour market & 28.0 & 16.8 & 12.2 & 6.2 & 1.4 & 12.9 \\
\hline Working more hours & 11.4 & 15.6 & 16.3 & 11.5 & 13.4 & 13.7 \\
\hline \multicolumn{7}{|l|}{ Time } \\
\hline Increasing production at home & 74.4 & 73.0 & 62.6 & 52.5 & 43.2 & 61.1 \\
\hline Dispensing with/cutting back on domestic service ${ }^{a}$ & . & . & 43.0 & 27.8 & 40.5 & 37.9 \\
\hline Migration & 4.3 & 2.3 & 6.0 & 5.1 & 4.6 & 4.5 \\
\hline
\end{tabular}

a The percentage for this item refers to households for which this category is relevant.

TABLE 26

\section{Argentina: Use of financial strategies}

\begin{tabular}{|c|c|c|c|c|}
\hline & \multicolumn{2}{|c|}{$\%$ of households opting to } & \multicolumn{2}{|c|}{$\%$ of households that reported a loss of income opting to } \\
\hline & Now & Before October 2001 & Now & Before October 2001 \\
\hline Sell assets & 3.7 & 1.1 & 5.5 & 1.0 \\
\hline Use savings & 5.1 & 3.0 & 7.1 & 4.9 \\
\hline Borrow from banks & 1.7 & 2.4 & 1.3 & 3.1 \\
\hline Buy on credit & 7.3 & 5.1 & 9.7 & 6.6 \\
\hline
\end{tabular}

TABLE 27

Argentina: Use of financial strategies, by income level

\begin{tabular}{lcccccc}
\hline Quintile & I & II & III & IV & V & Total \\
\hline Selling assets & 5.9 & 3.7 & 3.3 & 2.7 & 1.1 & 3.3 \\
Using savings & 2.8 & 3.5 & 4.0 & 8.0 & 5.6 & 4.8 \\
Borrowing from banks & 0.9 & 3.6 & 1.8 & 0.6 & 2.0 & 1.8 \\
Buying on credit & 14.6 & 13.1 & 9.5 & 2.3 & 0.7 & 8.0 \\
\hline
\end{tabular}

the lowest quintile tend to be net recipients and those in the highest quintile net givers.

Retrospective questions were used to identify changes in access to or use of social networks since October 2001. While the survey revealed an increase in various forms of social network use, the greatest increases were in the use of barter and participation in community activities. 
TABLE 28

Argentina: Use of social network strategies

\begin{tabular}{|c|c|c|}
\hline & $\%$ of households using & $\begin{array}{c}\% \text { of households that reported } \\
\text { a loss of income using }\end{array}$ \\
\hline Assistance from other people not living in the house ${ }^{a}$ & 16.3 & 17.0 \\
\hline Borrowing from friends or family & 10.7 & 13.7 \\
\hline Social plans & 6.9 & 7.5 \\
\hline Participation in community activities ${ }^{b}$ & 20.9 & 26.4 \\
\hline Barter & 11.1 & 15.2 \\
\hline Using at least one of these strategies & 37.0 & 42.5 \\
\hline Using more than one & 14.6 & 19.9 \\
\hline
\end{tabular}

a A higher percentage of households $(22 \%)$ claimed to provide assistance to people living in different households.

b Community activities include the following: school canteens, soup kitchens, community purchasing of goods, community workshops, fund-raising and community childcare, among others.

TABLE 29

Argentina: Use of social network strategies, by income level

\begin{tabular}{|c|c|c|c|c|c|c|}
\hline Quintile & I & II & III & IV & $\mathrm{V}$ & Total \\
\hline Assistance from other people not living in the house & 26.4 & 15.5 & 20.9 & 15.8 & 7.3 & 17.1 \\
\hline Assistance to other people not living in the house & 10.0 & 19.7 & 17.1 & 21.2 & 37.9 & 21.2 \\
\hline Borrowing from friends or family & 21.2 & 15.7 & 10.6 & 5.8 & 3.0 & 11.3 \\
\hline Social plans & 18.5 & 6.1 & 7.5 & 1.3 & 0.1 & 6.7 \\
\hline Participation in community activities & 29.4 & 23.6 & 22.8 & 15.7 & 15.7 & 21.4 \\
\hline Barter & 20.2 & 15.4 & 11.7 & 5.5 & 3.9 & 11.3 \\
\hline
\end{tabular}

TABLE 30

Argentina: Changes in the use of social networks

$\%$ of households using

Assistance from other people not living in the house

Borrowing from friends or family

Assistance from government or NGOs

Participation in community activities

Barter
$\%$ of households using before October 2001
The degree to which barter is used in low-income groups is made evident by the fact that the per capita income of households using it is less than the average for the population as a whole (143 pesos as against 214 , and 183 pesos as against 264, with and without adultequivalent adjustment, respectively). Households using barter tend to have more unemployed members $(43.3 \%$ as against $22.4 \%$ ) and more temporary workers (42\% as against $23 \%$ ), which is further proof of their vulnerability.
A similar pattern is observed for those households that report receiving some type of official help. Their per capita income is below average (122.7 pesos and 97.62 pesos, with and without adult-equivalent adjustment), they have a higher incidence of unemployment $(65 \%$ have an unemployed member), and those members that are employed are more likely to have temporary jobs $(80 \%)$.

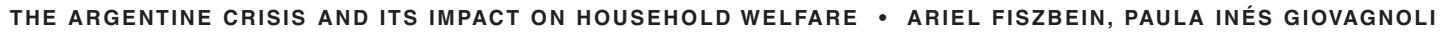




\section{IV}

\section{Conclusions}

This paper presents a variety of evidence for the magnitude of the social costs entailed by the Argentine economic crisis and its adverse effects at all income distribution levels. Household-level data confirm the negative picture yielded by analysis of the macroeconomic indicators available since early in the year.

Households are using a variety of coping strategies to respond to what is an intense crisis. The limited consumption data collected are not enough to establish the extent to which falling incomes are resulting in extreme forms of deprivation (i.e., the extent to which families' coping strategies are enabling them to avoid serious constraints). However, the scale of the shocks and the limitations on the effectiveness of the various coping mechanisms identified suggest that the effects on welfare are indeed very serious. The evidence points to greater effects on the use of health services than of education services, a conclusion that is being analysed in more detail using other sources of information.

A rapid comparison with events in other countries that have experienced similarly large economic shocks reveals some very interesting similarities as well as some specific differences. Fallon and Lucas's analysis (2002) of the effects on labour markets ${ }^{19}$ indicates a pattern of rising open unemployment rates and major changes in the sectoral composition of employment (sharp reductions in construction and manufacturing, the latter as the corporate sector is hit by the higher costs of imported materials, difficulties in obtaining credit and the rising burden of foreign-currency debt) similar to what has been observed in post-convertibility Argentina.

Evidence relating to the distributional impact of crises shows some differences between countries. Thomas, Frankenberg and others (1999) estimated that in the case of Indonesia per capita expenditure fell by more in the top and bottom quintiles of the distribution than among households in the middle of the distribution scale. In Thailand, by contrast, there is evidence of modest redistribution of income from the middleincome to the high-income classes. The data analysed

19 The countries analysed and their crisis years, in reverse chronological order, are: Indonesia (1998), Republic of Korea (1998), Malaysia (1998), Thailand (1997), Argentina (1995), Mexico (1995) and Turkey (1994). in the present work suggest that the decline of family income in Argentina has affected the middle class most.

Regarding coping strategies, Thomas, Frankenberg and others (1999) note that in Indonesia (as in the case of Argentina now) informal assistance from friends and family members was particularly important during the crisis, with about a quarter of all households receiving such assistance. Its mean value was considerably higher than that of assistance from official services. Sudarno, Wetterberg and Pritchett (1999) also found that coping strategies in Indonesia differed by income level. For instance, middle-class families responded by working longer hours, reducing consumption, drawing down savings and selling assets, while lower-income households resorted to more drastic measures, such as taking their children out of school.

Regarding this last point, the evidence is mixed. In Mexico during the 1982 crisis, for example, secondary school drop-out rates increased slightly while primary school drop-out rates fell. Both changes were part of long-term trends throughout the 1980s (Lustig, 1998). Similarly, Adam and Chamberlin (1999) did not find evidence of significant reductions in school participation in Thailand, although they too recognized the measurement difficulties and delayed responses that have been mentioned here. The evidence for Thailand, though, did find a gap in drop-out rates between poor and non-poor households, something that could also be identified (although not with precision) in the case of Argentina.

Lastly, even though the current crisis is much greater in scale than those experienced during the 1990s, the general characteristics of the coping strategies being seen now are very similar to those identified in previous studies on Argentina (World Bank, 2001), particularly the reliance on social networks and the changes in consumption patterns.

The next steps in this ongoing analysis will include more detailed studies of the impact of the crisis on health and education services, a more systematic analysis of the use of different coping strategies by household type (using multivariate methods), more specific consideration of the rural sector -making use of the unique coverage of this survey-and a particular focus on the role of migration as a coping strategy.

tHe ARGENTINE CRISIS AND ITS IMPACt ON HOUSEHOLd WELFARE • ARIEL FISZBEIN, PAULA INÉS GiOVAGNOLI 


\section{Bibliography}

Adam, S. and C. Chamberlin (1999): Thailand Social Monitor. Coping with the crisis in education and health, World Bank Report, No. 24467 TH, Washington, D.C.

De Ferranti, D., G.E. Perry and others (2000): Securing our future in a global economy, Washington, D.C., World Bank, June.

Dirección Nacional de Política Criminal (2000): Encuestas de victimización en Buenos Aires, Rosario, Córdoba and Greater Buenos Aires.

Estadísticas de Servicios Públicos (2002): Información de prensa, Buenos Aires, Instituto Nacional de Estadística y Censos (INDEC)/Ministerio de Economía.

Fallon, P.R. and R.E.B Lucas (2002): The impact of financial crises on labor markets, household income and poverty: a review of evidence, The World Bank Research Observer, vol. 17, No. 1, Washington, D.C.

Frankenberg, E., D. Thomas and K. Beegle (1999): The real costs of Indonesia's crisis: Preliminary findings from the Indonesia Family Life Surveys, Labor and Population Program Working Paper Series, No. 99-04, Santa Monica, California, Rand Corp., March.

Heckman, J. (1979): Sample selection as a specification bias, Econometrica, vol. 47, No. 1, January.
Loskin, M. and R. Yemtsov (2001): Household strategies for coping with poverty and social exclusion in post-crisis Russia, Policy Research Working Paper, Washington, D.C., World Bank.

Lustig, N. (1998): Mexico: The remaking of an economy, Washington, D.C., The Brookings Institution Press.

(2000): Crisis and the poor: Socially responsible macroeconomics, Journal of the Latin American and Caribbean Economic Association, vol. 1, No. 1, The Brookings Institution Press.

Sudarno, S., A. Wetterberg and L. Pritchett (1999): The social impact of the crisis in Indonesia: Results from a nationwide Kecamatan survey, East Asia Environment and Social Development Unit, No. 21249.

Thomas, D., E. Frankenberg and others (1999): Household budgets, household composition and the crisis in Indonesia: Evidence from longitudinal household survey data, paper presented at the Population Association Meeting of America, New York.

World Bank (2000): Poor people in a rich country: A poverty report for Argentina, Report, No. 19992-AR, Washington, D.C.

(2001): Household risk, self-insurance and coping strategies in urban Argentina, Report, No. 22426-AR, Washington, D.C. 